\title{
Layanan Perpustakaan Proklamator Bung Karno di Era Pandemi Covid-19
}

\author{
Laudia Saronyx \\ Jurusan Perpustakaan dan Ilmu Informasi Fakultas Sains dan Teknologi \\ UIN Maulana Malik Ibrahim Malang \\ Jalan Gajayana No. 50 Malang 65144 \\ Laudia635@gmail.com
}

\begin{abstract}
Abstrak - Adanya pademi covid 19 menyebabkan masyarakat melakukan aktifitas dirumah dengan melalui media online. Hal tersebut juga berdampak pada kegiatan di perpustakaan yang awalnya dilakukan secara langsung kini harus mengunakan media online. Yang mengharuskan seorang pustakawaan memutar otak untuk membuat inovasi baru guna keberlanjutas proses layanan perpustakaan di masa pandemi covid 19. Tujuan dari penelitian ini adalah metode pengembangan konsep pengembangan dari layanan perpustakaan proklamator bung karno yang telah melayani perpustakaan selama masa pandemi ini. Ada setiap pertemuan yang kita miliki adalah metode deskripsi, yang mengga mbarkan a tau mengga mbarkan penelitian terkini tentang sua tu topik atau objek berda sarkan fakta dalam membandingkan kasus-kasus ilmiah terkonsentra si di bidang perpustakaan dan informasidi. Riset kepustakaan terkait dengan pelayanan saat pandemi COVID-19 sedang berlangsung. Basis data ini diperoleh melalui pengamatan ke Perpustakaan Proklamator Bung Karno serta layanan perpustakaan online yang disediakan oleh situs Perpustakaan Prokla mator Bung Karno. Data merupakan proses dan disajikan dalam deskripsi sudah merupakan proses penyajian. Penelitian ini termasuk kedalam penelitian sosialda la m pemanfaatan teknologi informa si yang berupa la ya nan online dengan mengunakan internet sebagai layanan digital. Perpustakaan Proklamator Bung Karno memiliki beberapa layanan digital yang disediakan diantaranya layanan keanggotaan, layanan referensi dan peminja man. Dalam masa pandemic covid-19 perpustakaan Prokla mator Bung Karno menerapkan program SILAKAN dan SISKARLING yang bertujuan untuk mempermudah pemustakanya.
\end{abstract}

Kata Kunci : Perpustakaan, Pandemi Covid 19, Teknologi informasi, Layanan digital

\section{Pendahuluan}

Pada awal tahun 2020 muncul berita datangnya virus jenis baru yang berasal dari Cina. Dengan munculnya virus covid-19 mengakibatkan semua orang dianjurkan untuk tidak keluar dari rumah dan menjaga jarak dengan orang lain. Pada saat ini pemerintah telah menerapkan lockdown atau karantina wilayah untuk memutuskan mata rantai penyebaran virus COVID 19. ( Ibnu\&amp; Setiawan, 2018) UU No 6 Tahun 2018 Tentang Kekarantinaan Kesehatan dengan jelas menerangk an tentang terdapatnya pembatasan masuk- keluarnya orang ke sesuatu wilayah yang sudah dinyatakan sumber wabah, tercantum mengendalikan pula tentang terdapatnya perintah buat melaksanakan isolasi, karantina daerah, vaksinasi serta lain sebagainya untuk menghentikan penyebaran wabah yang terjadi di Indonesia. Perihal tersebut mengaharuskan warga melakuakan aktivitas aktivitas lewat online ataupun kerja dari rumah.

Dengan adanya pandemi covid-19 mengharuskan sebuah perpustakaan membuat inovasi baru dalam layanan perpustakaan. Pada saat ini banyak perpustakaan yang telah mengunakan media online atau digital untuk proses promosi dan layanan perpustakaan. ( Subrata\&amp; Kom, n. d.) Perpustakaan Digital 
merupakan suatu sistemyang mempunyai bermacam layanan serta obyek data yang menunjang akses obyek data tesebut lewat fitur digital. Layanan perpustakaan digital hampir sama dengan perpustakaan langsung( tatap muka) cuma saja lewat media yang bereda.

Pada saat ini seorang pustakawan diharuskan menguasai ilmu teknologi guna memingkatkan proses layanan dan promosi. Pustakawan juga wajib meningkatkan inovasi layanan untuk mengikuti perkembagan zaman. Pada saat ini semua kegiatan masyarakan dilakukan dengan mengunakan media online seperti proses jual beli, layanan informasi, layanan jasa dan masih banyak lagi.

(Subrata \& Kom, n.d.) perpustakaan adalah sebuah organisasi dan bertanggung jawab untuk mengumpulkan informasi, memproses, dan bermain, serta memenuhi kebutuhan informasi Perpustakaan kami. Dari pengertian tersebut dapat terlihat bahwa perpustakaan adalah sebuah organisasi, dimana pustakawan adalah sebuah institusi, dimana sekelompok orang bertanggung jawab atau menguasai dan menguasai perpustakaan. Perpustakaan juga mendukung proses pendidikan. Tugas utama pustakawan adalah mengumpulkan informasi, mengolah, menyajikan dan mencadangkan kebutuhan informasi pengguna perpustakaan. Oleh karena itu, seorang pustakawan wajib mengetahui tentang teknologi dan selalu mengikuti perkembagan zaman . Informasi ada dalam bentuk barang koleksi dalam bentuk cetak (seperti buku-buku dan majalah) atau non cetak (seperti, CD, film, dll).

Pada era pandemi covid 19 ini pestakawan harus menyajikan kebutuhan pemustakanya melalui media digital. Sebab dengan mengunakan media digital seorang pemustaka tidak perlu datang langsung ke perpustakaan melainkan hanya mengunakan alat elektronik seorang pustakawan bisa mengakses atau mengunakan layanan perpustakaan. Kebanyakan sumber informasi yang dib utuhkan oleh pemustaka di era pandemi covid 19 adalah buku, jurnal, laporan penelitian, dan masih banyak lagi. selain itu perpustkakaan digital juga melayani proses pendaftaran keanggotaan dengan melalui media online dengan melampirkan berkas-berkas secara online, tidak hanya itu prsoses peminjaman, administrasi dan kegiatan lainya dilakukan secara online.

Di Perpustakaan Proklamator Bung Karno juga menetapkan proses pelayanan melalui media online. Seperti proses pendaftaran anggota baru serta peminjaman buku pemustakan pemustaka melakukan secara online melalui media whatsapp. Dan apabila pemustaka ingin memijam buku fisik perpustakaan melayani proses tersebut dengan cara melihat katalog di situs online perpustakaan bungkama kemudia mengirimnya melalui whasaapsetelah itu pemustaka di beri waktu pengambilan selama dua hari di perpustakaan dengan menjalankan protokol Kesehatan. 


\section{Tinjauan Pustaka}

\section{A. Pengertian Layanan Perpustakaan}

Layanan Perpustakaan adalah penyediaan bahan pustaka dan atau sumber informasi secara tepat serta penyediaan sebagai layanan dan bantuan kepada pengguna pustaka sesuai kebutuhan pengguna pustaka. Menyajikan bahan pustaka dan atau sumber informasi sesuai kebutuhan pengguna pustaka, artinya bahwa dalam layanan perpustakaan, pustakawan perlu mencermati dan meminta masukan dari pengguna pustaka atas kebutuhsn bahan pustaka atau informasinya. Hakikat layanan perpustakaan adalah penyediaan segala bentuk bahan pustaka secara tepat dan akurat sesuai kebutuhan pemustaka penyediaan berbagai sarana penelusuran informasi. Selain menyediakan bahan pustaka yang dibutuhkan pemustaka, perpustakaan juga harus menyediakan sarana temu balik yang dapat memudahkan pemustaka untuk mencari bahan pustaka yang sesuai dengan kebutuhan informasinya (Rahayu, n.d.) .

\section{B. Tujuan Layanan Perpustakaan}

Tujuan layanan perpustakaan secara umum adalah agar koleksi yang disediakan oleh perpustakaan dapat dimanfaatkan semaksimal mungkin oleh pengguna pustaka secara efektif dan efisien. Yang dimaksud efektif dalam dalah hal ini adalah pengguna pustaka dapat memanfaatkan koleksi dan sumber informasi sehingga menghemat waktu mereka miliki (Ii et al., n.d.).

\section{Fungsi layanan Perpustakaan}

Fungsi kegiatan layanan perpustakaan adalah sebagai jembatan antara bahan pustaka yang dimiliki perpustakaan dengan pemustaka yang membutuhkannya guna mengoptimalisasikan pemanfaatan bahan pustaka/sumber informasi yang ada. Masing-masing jenis perpustakaan memiliki tujuan penyelenggaraan yang berbeda, demikian pula fungsi layanan perpustakaan. Oleh karena fungsi perpustakaan mendukung tujuan yang telah ditetapkan oleh masing-masing perpustakaan. (Rahayu, n.d.)

\section{Studi Terdahulu}

Penelitian mengenai Layanan Perpustakaan di Era Pandemi Covid 19 telah bayak diteliti di berbagai perpustakaan sebelumnya. Penelitian yang membahasa kemiripan topik maupun subjek penelitian menjadi acuan dalam penelitihan ini. Berikut merupakan penelitian terdahulu yang membahas Layanan perpustakaan di era pademi covid 19.

Riset yang dilakukan oleh Suharti Angkatan darat(AD)(2020) dalam harian Buletin Perpustakaan Universitas Islam Indonesia yang bertajuk“Layanan Bibliotek di Masa Pandemi Covid 19”. Tujuan dari riset ini buat mendeskripsikan media pelayanan perpustakaan sepanjang pandemi covid 19 sertaapakah ada 
pengaruh yang signifikan dari pandemi covid 19. Dalam harian tersebut peneliti menarangkan menimpa layanan penelusuran online disediakan buat memudahkan pemustaka dalam mencari data serta bertanya langsung kepada pustakawan yang bertugas di layanan online. Sumber data online yang awal kali diketahui merupakan katalog perpustakaan( OPAC). Layanan E- Resources Untuk mendukung keberhasilan serta kesuksesan aktivitas pembelajaran serta pendidikan di seluruh jenjang Pembelajaran. Layanan Repositori Institusi. Layanan Digital Library. Layanan Cek Plagiasi Online. Layanan Bebas Pustaka Online. Bimbingan Online, Literasi Data Online, Webinar, Konsultasi Perpustakaan\&amp; Kepustakawanan Online.

Hasil dari riset tersebut menampilkan kalau bermacam tipe layanan perpustakaan yang awal mulanya dicoba secara manual ataupun langsung saat ini dilakuakan secara online. Perihal tersebut bisa mempermudah pustakawan serta pemustaka yang diharuskan beraktifitas di dalam rumah. Pustakawan dapat berinovasi buat menolong pemustaka dalam mendapatkan data elektronik serta pelayanan administrasi lain yang diperlukan. Lewat bermacam inovasi pustakawan serta mendapatkan angka kredit buat peningkatan jabatan serta pangkatnya.

Dari riset diatas mempunyai persamaan dengan riset yang peneliti jalani ialah menimpa tema yang diteliti. Bersama mempelajari tentang layanan perpustakaan di masa pandemi covid 19. Sedangkan perbedaanya ialah mengenai obejek serta tempat yang diteliti. Riset yang hendak dilakukan peneliti lebih fokus ke media layanan berbasis online dan proses peminjaman.

Dengan demikian, meski tema dari riset tersebut serupa dengan riset yang penulis jalani. Akan namun mengingat subjek, objek serta tempat riset yang berbeda. Hingga peneliti tertarik buat melaksanakan riset tentang Lay anan Perpustakaan Proklamator Bung Karno di Masa Pandemi Covid 19.

\section{Metode Penelitian}

\section{A. Jenis Penelitian}

Di dalam penelitian ini seorang peneliti memilih metode untukmenggambarkan atau menggambarkan alur penelitian pada suatu topik atau objek berdasarkan fakta-fakta yang memanfaatkan karyailmiah di perpustakaan dan informasi lapangan. . studi pustaka terkait dengan layanan perpustakaan saat ini. Data tersebut diamati secara langsung dengan mengamati situs web Perpustakaan Umum Bung Karno tentang penyediaan layanan online. Data yang diolah dan disajikan di dalamnya mengolah penyajian deskripsi. Penelitian ini termasuk dalam penelitian sosial tentang pemanfaatan teknologi informasi berupa layanan online melalui pemanfaatan internet sebagai layanan digital. Fenomena penelitian yang mengkaji apa yang terjadi di dunia perpustakaan dan informasi di masa pandemi saat ini. Penelitian ini erat kaitannya dengan layanan perpustakaan dan teknologi informasi saat ini. Dan mengamati secara langsung layanan on line 
perpustakaan melalui website resmi Perpustakaan Proklamator Bung Karno. Data diolah dan disajikan dalam proses pemaparan secara deskriptif. Penelitian ini termasuk kedalam peneliyian sosial dalam pemanfaatan teknologi informasi yang berupa layanan online dengan mengunakan internet sebagai layanan digital. Penelitian fenomena yang diteliti mengenai hal terjadi dalam dunia perpustakaan dan informasi di masa pandemic saat ini. Penelitian ini berkaitan erat dengan layanan perpustakaan dan teknologi informasi pada era ini. Serta melakukan pengamatan secara langsung layanan perpustakaan secara online melalui website resmi dari perpustakaan perguruan tinggi tersebut.

\section{B. Teknik Pengumpulan Data}

Dalam penelitian ini penulis mengunpulkan data dengan Teknik wawancara dan observasi baik secara langsung dan melalui media sosial. Penggunaan Teknik tersebut dapat memudahkan penulis dalam memperoleh informasi secara menyeluruh. Karena dapat memahami keseluruhan data lapangan dan situasi. Observasi merupakan pengamatan langsunng dengan menggunakan penglihatan, penciuman, pendengaran, perabaan, atau kalau perlu dengan pengecapan. Instrumen yang digunakan dalam observasi dapat berupa pedoman pengamatan, tes, kuesioner, rekaman gambar, dan rekaman suara (Thalha Alhamid dan Budur Anufia, n.d.). Dengan Teknik observasi penulis dapat menemukan hal-hal yang belum terjawat saat melakukan wawancara. Wawancara ialah proses komunikasi atau interaksi untuk mengumpulkan informasi dengan cara tanya jawab antara peneliti dengan informan atau subjek penelitian. Dengan kemajuan teknologi informasi seperti saat ini, wawancara bisa saja dilakukan tanpa tatap muka, yakni melalui media telekomunikasi. Pada hakikatnya wawancara merupakan kegiatan untuk memperoleh informasi secara mendalam tentang sebuah isu atau tema yang diangkat dalam penelitian. Atau, merupakan proses pembuktian terhadap informasi atau keterangan yang telah diperoleh lewat teknik yang lain sebelumnya (PPs. UIN Maliki Malang, n.d.). Dan dengan Teknik wawancara penulis dapat mengumpulkan data dan informasi dari narasumber. Karena dengan wawancara penulis dapat menggali apa saja yang inggin penulis ketahui mengenai subjek atau topik yang ditelitinya.

\section{Hasil dan Pembahasan}

Berdasarkan Edaran (SE) Bupati Blitar nomor 2 tahun 2021 tentang perpanjangan waktu pemberlakuan pembatasan kegiatan masyarakat untuk mengendalikan penyebaran covid-19 di Blitar. Hal itu berpengaruh secara keseluruhan terhadap layanan di UPT. Perpustakaan Proklamator Bung Karno. Yang perlu adanya perubahan kebijakan layanan dalam menghadapi pandemi tersebut. Pengaruh yang ditimbulkan pada masa pandemic yaitu berupa jumlah kunjungan pemustaka yang mengalami penurunan, pelayanan peminjaman koleksi berubah menjedi pelayanan dengan cara online. Terkaid surat edaran tersebut UPT. Perpustakaan Proklamator Bung Karno melakukan upaya untuk tetap berperan dan berkontribusi dengan menciptakan 
pelayanan jarak jauh secara daring (online) kepada pemustaka terutama berkaitan dengan layanan yang ada di perpustakaan.

\section{Rata-rata Jumlah Anggota Baru}

Pada penelitian ini dilakukan secara observasi dan wawancara. Observasi secaralangsung bertujuan untuk mengetahui jumlah dan rata-rata jumlah anggota baru yang terdaftarpadatahun 2021. Pada bulan januari perpustakaan tutup dikarenakan adanya anjuran untuk tidak melakukan aktifitas diluar dikarenakan adanya virus covid-19. Hal tersebut dilakukan guna memutus mata rantai penyebaran virus covid-19. Pada tahun 2021 jumlah pendaftar menggalami penurunan dari tahun-tahun sebelumnya.

\begin{tabular}{|l|l|l|l|l|l|l|}
\hline NO & BULAN & PELAJAR & $\begin{array}{l}\text { MAHASIS } \\
\text { WA }\end{array}$ & $\begin{array}{l}\text { PEGAWAI } \\
\text { NEGERI }\end{array}$ & UMUM & JUMLAH \\
\hline 1 & JANUARI & 0 & 0 & 0 & 0 & 0 \\
\hline 2 & FEBRUARI & 4 & 3 & 0 & 37 & 44 \\
\hline 3 & MARET & 0 & 7 & 0 & 64 & 71 \\
\hline 4 & APRIL & 1 & 2 & 0 & 77 & 80 \\
\hline 5 & MEI & 2 & 3 & 0 & 40 & 45 \\
\hline & JUMLAH & 7 & 15 & 0 & 218 & $\mathbf{2 4 0}$ \\
\hline & $\begin{array}{l}\text { RATA2 PER } \\
\text { BULAN }\end{array}$ & 1 & 1 & 0 & 18 & $\mathbf{2 0}$ \\
\hline
\end{tabular}

Table 1. Rata-rata Jumlah Anggota Baru Pada Tahun 2021

\section{Rata-rata Jumlah Koleksi Buku Terpinjam}

Pada tahun 2021 perpustakaan menggalami penurunan pada peminjaman koleksi. Terutama pada bulan maret tahun 2021 perpustakaan mengalami penurunan secara drastis. Semenjak itu perpustakaan mulai menerapkan program SILAKAN guna meningkatkan Kembali jumlah peminjam koleksi. Semenjak adanya program SILAKAN perpustakaan sedikit demi sedikit mengalami peningkatan dalam hal peminjaman koleksi.

\begin{tabular}{|c|c|c|c|c|c|c|c|c|c|c|}
\hline \multirow{2}{*}{ NO } & \multirow{2}{*}{ NAMA KOLEKSI } & \multicolumn{5}{|c|}{ BULAN } & \multirow{2}{*}{ TOTAL } & \multirow{2}{*}{$\begin{array}{l}\text { RATA-RATA } \\
\text { PER BULAN } \\
\text { (per koleksi) }\end{array}$} & \multirow{2}{*}{$\begin{array}{c}\text { RATA- } \\
\text { RATA PER } \\
\text { HARI (per } \\
\text { koleksi) } \\
\end{array}$} & \multirow{2}{*}{ KET. } \\
\hline & & JANUARI & PEBRUARI & MARET & APRIL & MEI & & & & \\
\hline 1 & KOL. UMUM & TUTUP & 310 & 38 & 510 & 621 & 1.479 & 123 & 4 & \\
\hline 2 & KOL. ANAK & TUTUP & 15 & 25 & 11 & $\begin{array}{l}\text { Belum } \\
\text { Input }\end{array}$ & 51 & 4 & 0 & \\
\hline & JUMLAH & - & 325 & 63 & 521 & 621 & 1.530 & 128 & 4 & \\
\hline & $\begin{array}{c}\text { RATA-RATA } \\
\text { PERHARI }\end{array}$ & - & 11 & 2 & 17 & 21 & & & & \\
\hline
\end{tabular}

Table 2. Rata-rata Jumlah Koleksi Buku Terpinjam Tahun 2021 


\section{A. Layanan Perpustakaan di UPT. Perpustakaan Proklamator Bung Karno}

Perpustakaan Perpustakaan Proklamator Bung Karno menyediakan beberapa layanan bagi pemustaka diantaranya yaitu layanan keanggotaan, layanan referensi , layanan E-resources, layanan audio visual, layanan kunjungan, perpustakaan keliling, dan terbitan berkala.

Pada layanan keanggotaan yaitu layanan yang melayani proses pendaftaran, pembuatan kartu anggota, perpanjangan kartu, dan pengurusan kehilangan kartu anggota. Seorang anggota memiliki syarat, hak, dan kewajiban menjadi anggota perpustakaan.

Layanan referensi Adalah layanan pada UPT Perpustakaan Proklamator Bung Karno yang menyediakan buku-buku referensi yang tujuannya sebagai bahan rujukan. Berupa: Almanak, Annual, atlas, bibliografi, buku pegangan, buku pintar, buku saku, direktori, ensiklopedi, glosarium, indeks, kamus, katalog, laporan, peraturan, peta, sejarah, sumber biografi, sumber geografi, thesaurus, undang-undang, pahlawan.

Layanan E-resources berfungsi Untuk memenuhi kebutuhan pemustaka, kami melanggan berbagai bahan perpustakaan digital online (e-Resources) seperti jurnal, ebook, dan karya-karya referensi online lainnya. Koleksi film-film yang berhubungan dengan Bung Karno yang berjumlah 25 buah yang antara lain : Pidato-pidato Bung Karno di berbagai kegiatan kenegaraan, dan Film-film dokumenter tentang Bung Karno, Koleksi e-book sebanyak 10 judul yang antara lain : Amanat Presiden, Dekrit Presiden, Judul yang berkaitan dengan pancasila, E-resources baik dari dalam maupun luar negeri yang antara lain : ProQuest, Gale - Cengage Learning, Mylibrary, Sage, Ulrichs - Periodicals Directory, EBSCO Host, IGI Global, Westlaw, ISEAS, ALA Publishing, dll. Koleksi e-bulletin yang meliputi 3 majalah yang antara lain terdiri dari : Visi pustaka, Jumantara, Media Pustakawan.

Layanan audiovisual Memberikan fasilitas bagi kunjungan baik siswa, peserta diklat, mahasiswa maupun lembaga untuk melihat koleksi film-film yang berhubungan dengan Bung Karno, yaitu Pidatopidato Bung Karno di berbagai kegiatan kenegaraan, dan Film-film dokumenter tentang Bung Karno. Layanan kunjungan Menerima dan melayani kunjungan baik siswa, peserta diklat, mahasiswa maupun lembaga untuk melihat dan melakukan studi banding tentang aktivitas layanan perpustakaan dan informasi di UPT Perpustakaan Proklamator Bung Karno. Namun selama masa pandemic proses layanan kunjugan sementara diberhentikan.

Layanan Perpustakaan Keliling dan Kegiatan Pinjaman Massal untuk meningkatkan minat baca dengan menggunakan Layanan Mobil Perpustakaan Keliling sebagai sarana untuk mempermudah masyarakat dalam memanfaatkan fungsi perpustakaan. Dan dengan meminjam paket koleksi buku agar masyarakat dapat memanfaatkan koleksi buku tersebut dalam kurun waktu tertentu. Layanan ini juga telah ditangguhkan selama pandemi. 


\section{B. Penerapan Program SILAKAN dan SISKARLING}

Program SILAKAN (system layanan anda pesan kami antar) adalah suatu program layanan di perpustakaan Perpustakaan Proklamator Bung Karno. Layanan ini adalah salah satu inovasi dari pustakawan guna untuk memudahkan pemustaka. Layanan ini bertujuan agar perpustakaan tetap berperan dan berkontribusi walaupun dalam suasana panemi covid-19. Dimana SILAKAN berperan dalam proses pinjam-meminjam koleksi atau bahan Pustaka. Dengan cara pemustaka yang meminjam koleksi secara online berupa cetak kemudian koleksi tersebut akan diantarkan sampai tempat tujuan secara gratis. Saat menerapkan SILAKAN pemustaka terlebih dahulu melihat koleksi buku melalui web resmi OPEC Perpustakaan Proklamator Bung Karno. Kemudian pemustaka dapat juga menanyakan koleksi melalui nomor hotline yang di sediakan di dalam web tersebut. Penagihan atau pengembalian koleksi yang sudah terlambat yaitu sesuai program yang telah ditetapkan oleh Perpustakaan Proklamator Bung Karno dengan melakukan penagihan Kembali koleksi oleh pustakawan. Jumlah bukuyang dipinjamkan maksimal 2 (dua) eksemplar; 2. Waktu peminjaman koleksi selama 7 (tujuh) hari. Apabila pemustaka terlambat melakukan pengembalian maka pemustaka tersebut akan mendapat saksi. Dan bagi pemustaka yang menghilangkan koleksi dari perpustakaan maka pemustaka wajib menganti dengan koleksi yang sama. Perpanjangan koleksi dapat dilakukan selama satu hari dengan menambahkan tuju hari dari tanggal dilakukannya perpanjangan.

Penerapan program SISKARLING (system pendaftaran kartu anggota keliling) adalah salah satu program yang diterapkan pada era pandemic covid-19. SISKARLING merupakan suatu program dimana pemustaka akan melakukan kegiatan pendaftaran secara keliling kepada pemustaka yang akan mendaftar. Sistem ini juga biasa disebut dengan sistem jemput bola. Dengan sistem ini pemustaka tidak perlu dating jauh jauh keperpustakaan. Selama masa pandemic covid-19 Perpustakaan Proklamator Bung Karno juga menerapkan layan keanggotaan secara online. Layanan tersebut berisi tentang pendaftaran anggota yang dapat dilakukan secara online. Dengan cara pemustaka mengisikan formular secara online. Kemudian mendatangi perpustakaan untuk melakukan foto dan pencetakan kartu anggota.

\section{Kesimpulan dan saran}

\section{A. Kesimpulan}

Layanan perpustakaan Proklamator Bung Karno selama masa pandemic covid-19 dilakukan secara digital. Layanan perpustakaan Proklamator Bung Karno dapat diakses melalui webside resmi milik perpustakaan. Didalam webside tersebut terdapat beberapa layanan diantarannya, layanan keangotaan, layanan referensi dan masih banyak lagi. Selama masa pandemic covid-19 perpustakaan mengalami penurunan baik dalam jumlah pengunjun maupun jumlah peminjam koleksi. Dengan adanya penurunan 
tersebut pustakawan memulai memutar otak agar perpustakaan tetap berjalan meski dalam keadaan pandemi. Dalam proses peminjaman koleksi perpustakaan menerapkan SILAKAN dengan program tersebut dapat memudahkan anggota dalam melakukan peminjaman. Proses pendaftaran anggota dapat dilakukan dengan melalui media online terkadang perpustakaan jiga menerapkan program SISKARLING dengan mendatangi secara langsung anggota yang ingin mendaftar. Dengan adanya beberapa layanan dan sistem yang dijalankan di perpustakaan Proklamator Bung Karno dapat menhidupkan perpustakaan meskipun dalam suasana pandimi covid-19.

\section{B. Saran}

1. Untuk mpengembagan dan pengadaan layanan perpustakaan maka dapat mengimplementasiakan kebutuhan pengguna dan cara mempermudah pengguna dalam mengakses media yang telah disediakan.

2. Meskipun dalam keadaan pandemic covid-19 perpustakaan seharusnya tetap melayani secara langsung. Dengan menerapakan protocol Kesehatan dan pembatasan jumlah pengunjung. Dengan dadanya pelayanan secara langsung dapat memudahkan pemustaka yang sedang melakukan penelitian.

3. Penulis mengharapkan kritik dan saran yang membagun dalam penulisan artikel dikemudian hari. 


\section{VI. . Daftar Pustaka}

Ad, S. (2020). LAYANAN PERPUSTAKAAN DI MASA PANDEMI. 3(2), 53-63.

Ibnu, Y., \& Setiawan, S. (2018). Penetapan Karantina Wilayah Menurut Pandangan Legal Positivisme Dalam Rangka Pencegahan dan Pemberantasan Pandemi Coronavirus Disease ( Covid) -19. 1-16.

Ii, B. A. B., Perpustakaan, P. M., \& Perpustakaan, L. (n.d.). Ibid .h.20. 8. 8-46.

PPs. UIN Maliki Malang. (n.d.). Metode Pengumpulan Data Penelitian Kualitatif (Materi. 1-4.

Rahayu, L. (n.d.). Dasar-dasar Layanan Perpustakaan. 1-43.

Subrata, O. G., \& Kom, S. (n.d.). Perpustakaan digital. 1-11.

Thalha Alhamid dan Budur Anufia. (n.d.). INSTRUMEN PENGUMPULAN DATA. 1-20. 


\section{Lampiran}

\section{Transkrip Wawancara Peneliti}

Narasumber : : Indrawan Gambiro ( Pustakawan Perpustakaan Proklamator Bung Karno) Hari/Tanggal : : Selasa, 20 April 2021

Topik Wawancaraan : Pengaruh adanya pandemi covid 19 dalam proses layanan perpustakaan Wawancara dilakukan secara online melalui media WhatsApp

\begin{tabular}{|c|c|}
\hline Peneliti & $\begin{array}{l}\text { Assalamu'alaikum mohon maaf telah menggangu waktu bapak, apakah saya } \\
\text { bisa memulai melakukan wawancara dengan Bapak? }\end{array}$ \\
\hline Pustakawan & am, silahkan \\
\hline Peneliti & Bagaimana pengaruh pandemi covid 19 terhadap layanan perpustakaan ? \\
\hline pustakawan & $\begin{array}{l}\text { Pandemi covid } 19 \text { sangat berpengaruh terhadap layanan di UPT. Perpustakaan } \\
\text { Proklamator Bung Karno. Berpengaruh secara keseluruhan sehingga perlu } \\
\text { adanya perubahan kebijakan layanan dalam menghadapinya. }\end{array}$ \\
\hline Peneliti & $\begin{array}{l}\text { Apa saja dampak dari pandemi covid terhadap perpustakaan Proklamator } \\
\text { Bung Karno? }\end{array}$ \\
\hline Pustakawan & $\begin{array}{l}\text { Dampak dari pandemi covid } 19 \text { adalah Jumlah kunjungan pemustaka yang } \\
\text { mengalami penurunan. Perlakuan terhadap koleksi yang berbeda dengan } \\
\text { sebelumnya, dimana harus melewati proses karantina koleksi. Jumlah Koleksi } \\
\text { Terpinjam menurun. Jumlah Pendaftaran Keanggotaan menurun. Pelayanan } \\
\text { peminjaman koleksi berubah menjadi pelayanan dengan cara online }\end{array}$ \\
\hline Peneliti & Seperti apakah layanan perpustakaan di era pandemi covid? \\
\hline Pustakawan & $\begin{array}{l}\text { Selama masa pandemi pelayanan dilakukan dengan memanfaatkan teknologi } \\
\text { informasi diantaranya Penerapan program SILAKAN (Sistem Layanan Anda } \\
\text { Pesan Kami Antarkan) yaitu suatu program layanan perpustakaan } \\
\text { Proklamator Bung Karno dimana pemustaka meminjam koleksi secara } \\
\text { online kemudian koleksi diantarkan sampai tempat tujuan secara gratis. } \\
\text { Penerapan SISKARLING (Sistem Pendaftaran Kartu Anggota Keliling) } \\
\text { yaitu suatu program dimana perpustakaan akan melakukan kegiatan } \\
\text { pendaftaran secara keliling kepada pemustaka yang akan mendaftar (jemput }\end{array}$ \\
\hline
\end{tabular}




\begin{tabular}{|c|c|}
\hline & $\begin{array}{l}\text { bola). Penagihan / pengambilan Koleksi yang sudah terlambat, yaitu suatu } \\
\text { program yang dilakukan oleh perpustakaan Proklamator Bung Karno dengan } \\
\text { melakukan penagihan/pengambilan koleksi yang terlambat dikembalikan } \\
\text { oleh pemustaka. Penyampaian informasi dan pengaduan yang dilakukan } \\
\text { secara online di nomor hotline perpustakaan. Konsultasi keBungKarnoan } \\
\text { juga dilakukan secara online di nomor hotline perpustakaan. }\end{array}$ \\
\hline Peneliti & $\begin{array}{l}\text { Bagaimana cara pemustaka yang ingin melakukan pendaftaran keanggotaan } \\
\text { pada era pandemi covid. ? }\end{array}$ \\
\hline Pustakawan & $\begin{array}{l}\text { Dengan melakukan Pendaftaran Keanggotaan dilakukan secara online di } \\
\text { alamat http://bit.ly/keanggotaanperpusbungkarno, Pemustaka mengisi } \\
\text { formulir online tersebut, kemudian mendatangi Perpustakaan Proklamator } \\
\text { Bung Karno untuk dilakukan foto dan pencetakan kartu. Serta penerapan } \\
\text { SISKARLING. }\end{array}$ \\
\hline Peneliti & $\begin{array}{l}\text { Layanan apa saja yang ditawarkan oleh Perpustakaan Proklamator Bung } \\
\text { Karno ? }\end{array}$ \\
\hline Pustakawan & $\begin{array}{l}\text { Perpustakaan Proklamator Bung Karno menyediakan layanan keanggotaan, } \\
\text { layanan referensi, layanan layanan E-resources, layanan audio visual, layanan } \\
\text { kunjungan, perpustakaan keliling, dan terbitan berkala. }\end{array}$ \\
\hline Peneliti & $\begin{array}{l}\text { Baik, terimakasih sudah meluangkan waktu untuk melakukan wawancara } \\
\text { dengan saya. Apabila saya ada kata atau kesalahan mohon maaf. } \\
\text { Wasalamualaikum terimakasih Pak. }\end{array}$ \\
\hline Pustakawan & salam, sama-sama semoga bermanfaat. \\
\hline
\end{tabular}




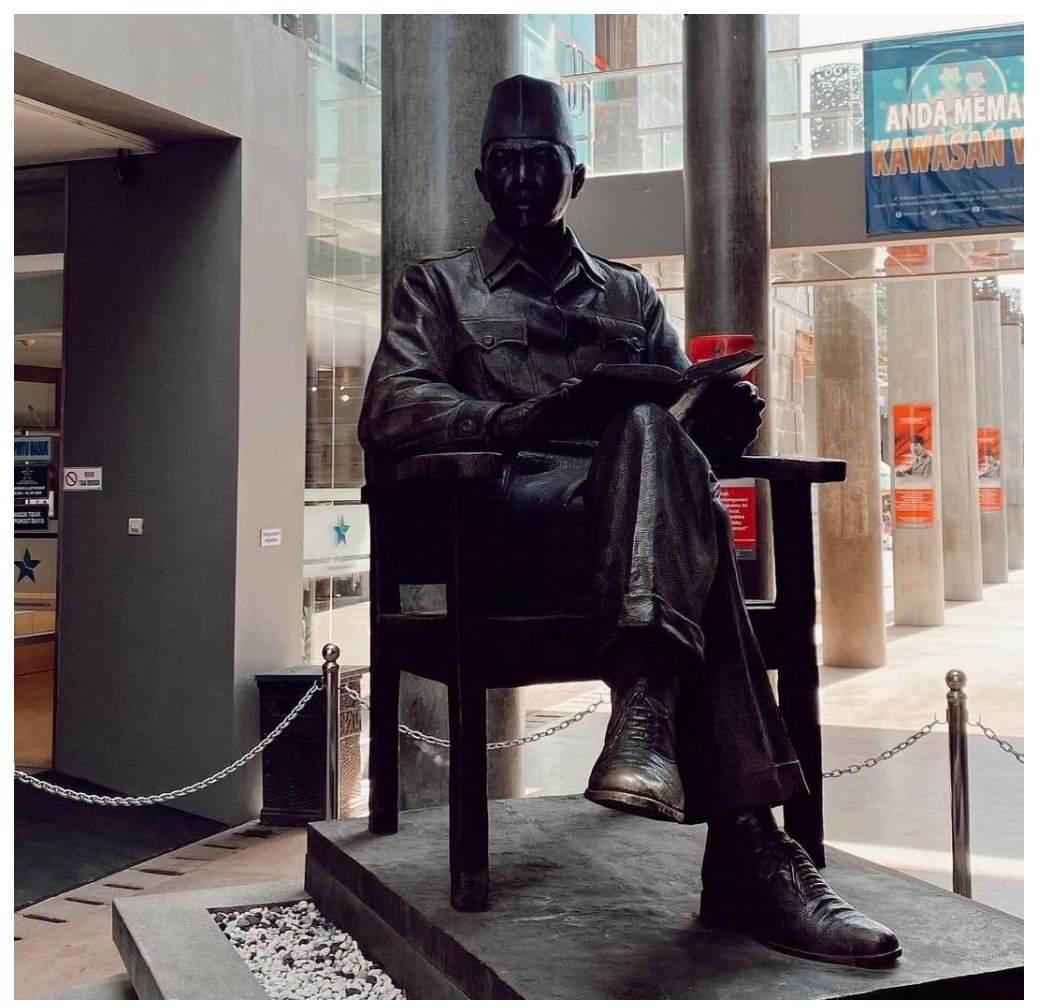

Gambar 1. Patung Bung Karno

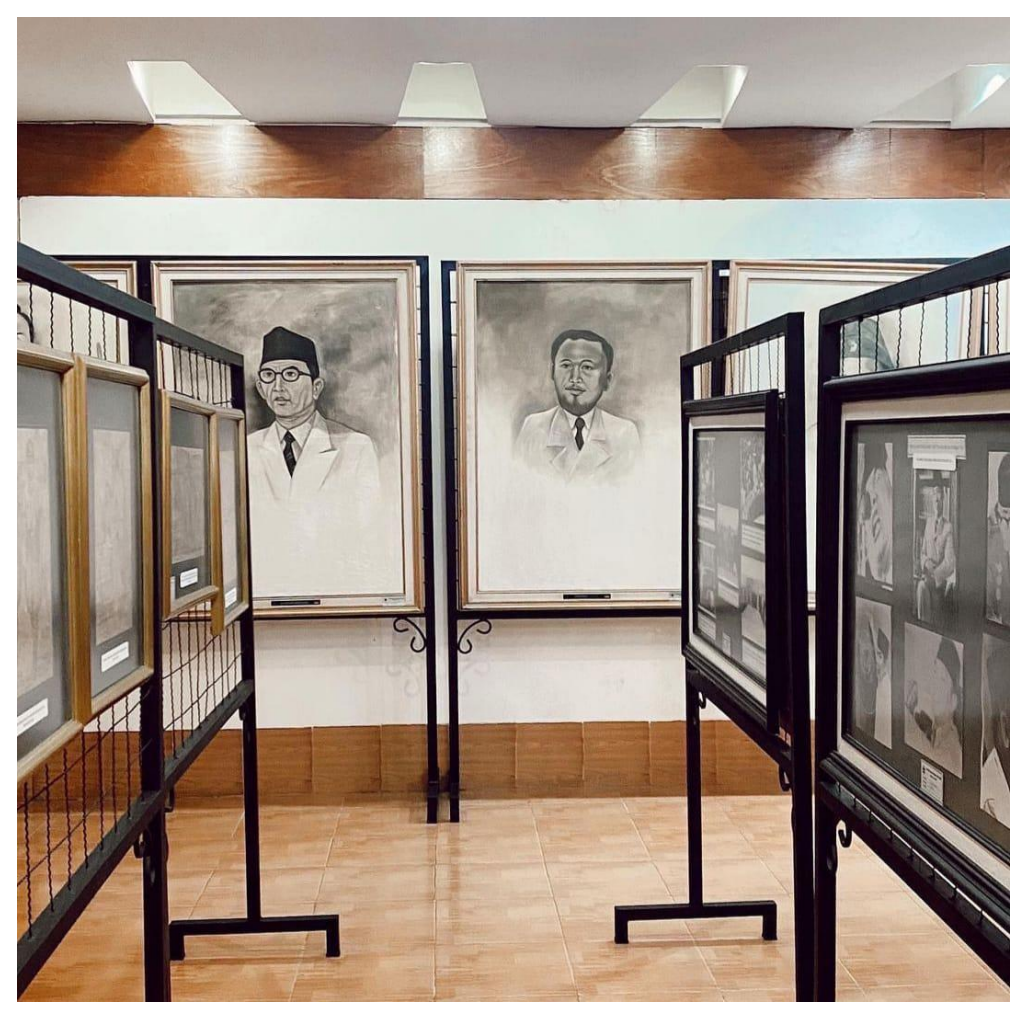

Gambar 2. Museum Bung Karno 


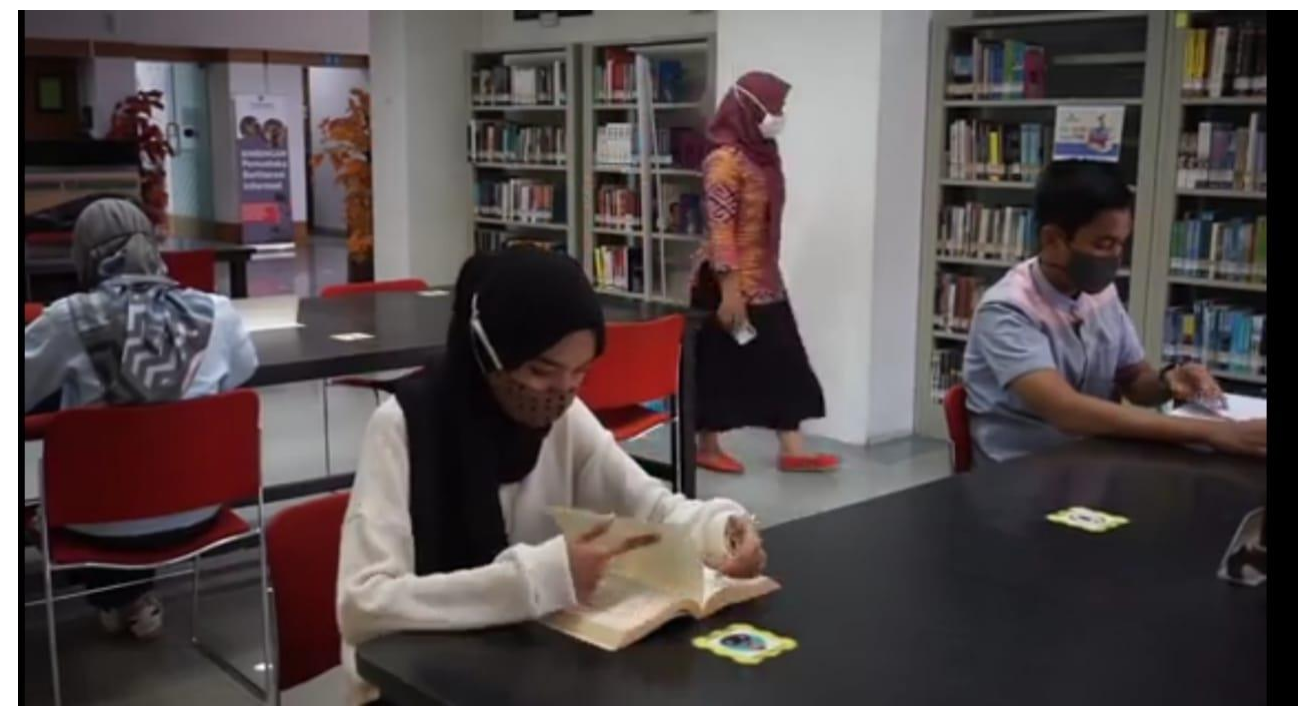

Gambar 3. Ruang baca Perpustakaan Proklamator Bung Karno

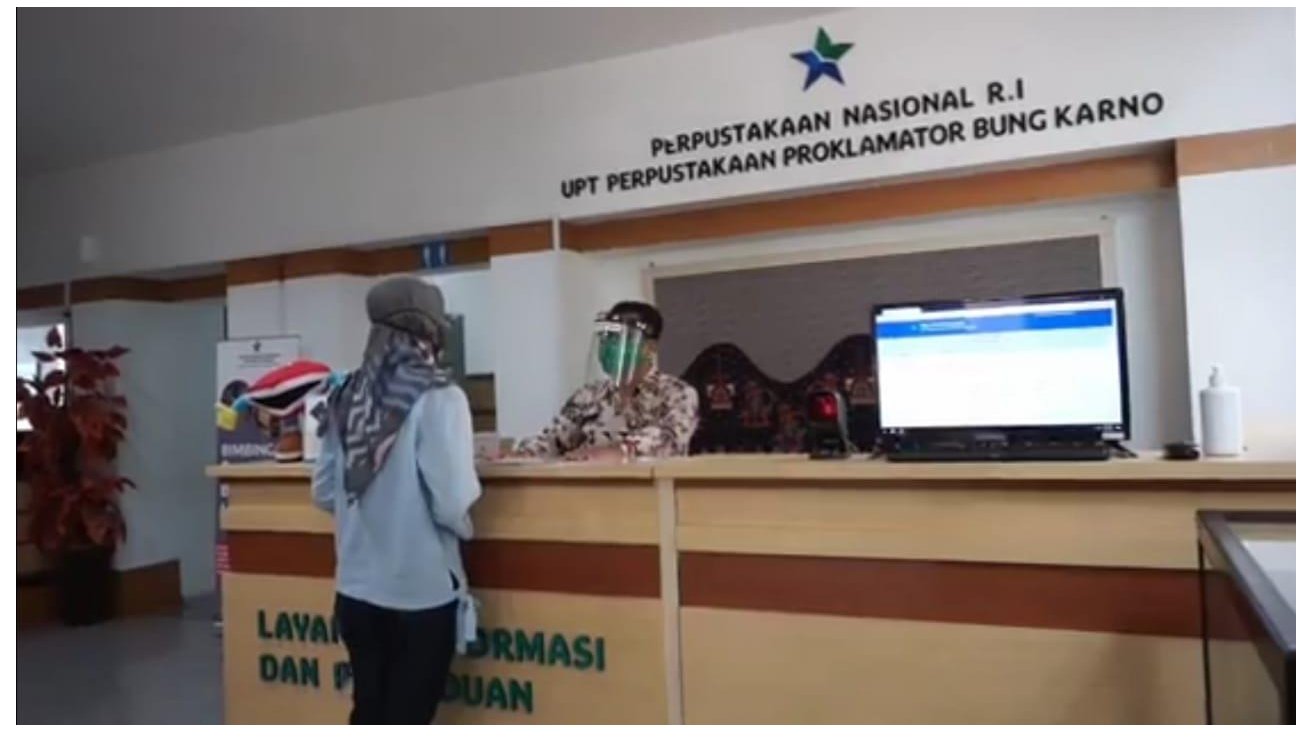

Gambar 4. Ruang Layanan Informasi dan Panduan

Perpustakaan Proklamator Bung Karno 